\title{
CORRELATION OF SOCIAL DEPRIVATION ON THE MENTAL HEALTH AMONG THE CLUSTER 7 TEACHERS IN CALAMBA CITY, LAGUNA, SCHOOL YEAR 2020-2021
}

\author{
Mart Albert A. De Guzman \\ MAED Students, Laguna State Polytechnic University
}

Article DOI: $\underline{\text { https://doi.org/10.36713/epra7290 }}$

DOI No: 10.36713/epra7290

\begin{abstract}
This study aimed to analyze the relationship of social deprivation on the mental health among the Cluster 7 teachers in Calamba City, Laguna. Specifically, this study sought to answer the following questions: (1) Level of social deprivation on the mental health among the Cluster 7 teachers in Calamba City Laguna in terms of Social Isolation and Interpersonal Communication. (2) Level of mental health of Cluster 7 teachers in Calamba City, Laguna in terms of State of mind, Behavior, Thinking, and Self-Esteem. (3) Is there a significant relationship between social deprivation and the mental health among the Cluster 7 Teachers in Calamba City, Laguna?

The descriptive method of research design was used in this study to arrive at more conclusive proof and primarily to analyze the data systematically. The online questionnaire checklist which is composed of thirty (30) questions, where five (5) question for social interaction, five (5) question for personal communication, five (5) question for state of mind, five (5) for behavior, five (5) Thinking, five (5) self-esteem. The data collected was treated with the used of weighted mean level and standard deviation as basis for the statistical treatment of data to analyze the relationship of social deprivation on the mental health among the Cluster 7 teachers in Calamba City, Laguna. The weighted mean and standard deviation were computed by the average of the response in the self-made online survey. The Pearson- $R$ for the correlated mean was used in order to find out the strength of the relationship between two variables and their association with each other are jointly significant especially on the correlation on social deprivation on the mental health among the Cluster 7 teachers in Calamba City, Laguna.

Based on the data, it is shown that there is "a relationship between the social deprivation to the mental health among the Cluster 7 teachers in Calamba City" at 0.05 level of significance. It shows that the null hypothesis stating that "There is no significant relationship between the social deprivation to the mental health among the Cluster 7 teachers in Calamba City" is rejected, it can infer that there is "significant" relationship between them.

Based on the findings and conclusions the following recommendations were made; The Public Schools may be encouraged to better promote Mental Health awareness to all the school personnel; The Teachers may be encouraged more to be open minded and be aware in taking care their mental being; The DepEd may provide training and seminars for the school guidance counselor in adapting societal change and promote Mental Health awareness; The future researcher may have further study on the relationship and effect of social deprivation on the mental health of a person and to have a better understanding on how social deprivation be diminish in the society; The researcher suggested to have further study about the social deprivation or about on the same field and promote the care for our mental well-being.
\end{abstract}




\section{EPRA International Journal of Research and Development (IJRD) \\ Volume: 6 | Issue: 6 | June 2021 \\ - Peer Reviewed Journal}

\section{INTRODUCTION}

Health is a concept influenced by a set of complex factors such as biological, psychological, social, cultural, economic and spiritual, it should be acknowledged that health and mental illness do not simply have biological or psychological aspects, but also have concurrent social dimensions and nature. Social factors, which can play an important role in creating, maintaining, and promoting health, have been a major role in incidence, prevalence and persistence of the disease. On the other hand, it is very important to pay attention to social factors influencing mental health, and perceived social support is one of those factors. Social support represents the amount of support that a person perceives and reports receive it. Social sustenance is a phenomenon that involves interactions of people so that when a person offers social interaction, it has an important role in his health. Social support provides physical and psychological advantages for people faced with stressful physical and psychosocial events, and is considered as a factor reducing the psychological distress when faced with stressful events.

COVID-19 outbreak in the Philippines resulted operation freeze in some agency of the government as well as schools and educational institutions. Many industries even government agencies that provide public services were also affected by this pandemic especially the Department of Education. Due to the threat of the pandemic, people are being deprive to have a social and personal interaction to people whom they regularly interacted with that contributes to who they are as a person. Thus, being socially and personally confined inside their homes, this is affecting their overall mental and emotional health. Due to quarantine and lockdown of the various places, people were prevented to go out and ordered to stay inside their homes and they were unable to socialized and interact to their family, friends, and co-workers that causes psychological disturbance such as mental stress, anxiety, and depression. According to Hawlky cited by Amy Novotney (2019) points to evidence linking perceived social isolation with adverse health consequences including depression, poor sleep quality, impaired executive function, accelerated cognitive decline, poor cardiovascular function and impaired immunity at every stage of life. According to (Holt-Lunstad, Smith, \& Layton, 2017) A robust body of scientific evidence has indicated that being embedded in high-quality close relationships and feeling socially connected to the people in one's life is associated with decreased risk for all-cause mortality as well as a range of disease morbidities. According to David White (2016) disconnection from the larger society is known as social deprivation, and it can have serious consequences for those who experience it. Social deprivation is a broad and somewhat poorly defined umbrella term that refers to the combination of factors that prevent a person from having easy and frequent access to the many different aspects of their culture and society. Thus, social deprivation and isolation affects persons' over-all health especially this time of the global pandemic. Hence, this research intends to analyze the relationship of social deprivation on the mental health of Cluster 7 teachers in Calamba City, Laguna. The Cluster 7 teachers will be the respondents of this study. Thus, the researcher aims to help the school in Cluster 7 in Calamba City, Laguna to analyze the effect of social deprivation on the mental health of Cluster 7 teachers in Calamba City, Laguna.

\section{MATERIALS AND METHODS}

Descriptive research design was used in this study because this was intended to prove or test an idea to analyze the relationship of social deprivation on the mental health of Cluster 7 teachers in Calamba City, Laguna.

The first step was the identifying the problem. After the problem, was identified the researcher collected the information about the variables of the problem. The researcher prepared a self-made online survey that run for reliability test and used thirty public school teachers from different school in Calamba City, Laguna. After the reliability test was done the questionnaire undergone validation of three licensed Psychometrician. Then the researcher made a letter of permission that was signed by the principal of the different schools in Cluster 7, Calamba City, Laguna. After that, the researcher gathered the necessary data that will be tabulated and computed.

The researcher used 30\% of the teacher's population per school in Cluster 7 in Calamba City, Laguna as the respondent of the self-made research survey, which consist of 6 Elementary School and 1 High School with the total of 91 teachers.

As a researcher's instrument, a self-made online survey questionnaire was used to gather the necessary data to analyze the relationship of social deprivation on the mental health among the Cluster 7 teachers in Calamba City, Laguna and this were rated with the used of Likert Scale.

The data collected was treated with the used of weighted mean level and standard deviation as basis for the statistical treatment of data to analyze the relationship of social deprivation on the mental health among the Cluster 7 teachers in Calamba City, Laguna. 


\section{EPRA International Journal of Research and Development (IJRD) \\ Volume: 6 | Issue: 6 | June 2021 \\ - Peer Reviewed Journal}

The weighted mean and standard deviation were computed by the average of the response in the self-made online survey.

The Pearson-R for the correlated mean was used in order to find out the strength of the relationship between two variables and their association with each other are jointly significant especially on the correlation on social deprivation on the mental health among the Cluster 7 teachers in Calamba City, Laguna.

\section{RESULT AND DISCUSSION}

Level of social deprivation on the mental health among the Cluster 7 teachers in Calamba City Laguna in terms of Social Isolation.

Based on the teachers' perceptions, the level of social deprivation on the mental health with regard to social Isolation was generally high. Feeling connected with the person you love $(\mathrm{M}=4.16, \mathrm{SD}=1.128)$ and have this feeling of social connection with their friends $(\mathrm{M}=3.73, \mathrm{SD}=1.126)$. The teachers are able to do the things you want to do $(\mathrm{M}=3.38, \mathrm{SD}=1.200)$; this item got the lowest rating. All item indicators got a verbal interpretation of moderately of high to high, as disclosed by the overall mean of 3.72 and supported with standard deviation of 1.147.

This meant that the teachers were able to manage the mental health at a high extent. This is done by doing things with the person you want to work on and to be connected with your friends.

Table 1. Level of social deprivation on the mental health among the Cluster 7 teachers in Calamba City Laguna in terms of Social Isolation

\begin{tabular}{|l|c|c|c|}
\hline During this time of home quarantine & Mean & SD & Remarks \\
\hline Feeling of socially connected. & 3.70 & 1.130 & Agree \\
\hline I have this feeling of social connection with my friends. & 3.73 & 1.126 & Agree \\
\hline Feeling connected with the person you love. & 4.16 & 1.128 & Agree \\
\hline Being able to do the things you want to do. & 3.38 & 1.200 & $\begin{array}{c}\text { Moderately } \\
\text { Agree }\end{array}$ \\
\hline $\begin{array}{l}\text { There's a sense of delight and warmed of other people } \\
\text { company. }\end{array}$ & 3.64 & 1.028 & Agree \\
\hline $\begin{array}{l}\text { Overall Mean = 3.72 } \\
\text { Standard Deviation }=\mathbf{1 . 1 4 7} \\
\text { Verbal Interpretation = High }\end{array}$ & & \\
\hline
\end{tabular}

Legend:

Scale Range Remarks

5

4

3

2

1

$\begin{array}{ll}4.20-5.00 & \text { Strongly Agree } \\ 3.40-4.19 & \text { Agree } \\ 2.60-3.39 & \text { Moderately Agree } \\ 1.80-2.59 & \text { Disagree } \\ 1.00-1.79 & \text { Strongly Disagree }\end{array}$

Verbal Interpretation
Very High
High
Moderately High
Low
Very Low

Level of social deprivation on the mental health among the Cluster 7 teachers in Calamba City Laguna in terms of Interpersonal Communication.

Table 2. Level of social deprivation on the mental health among the Cluster 7 teachers in Calamba City Laguna in terms of Interpersonal Communication

The teachers observed that the social deprivation showed a high level of mental health with regard to Interpersonal Communication in terms telling easily your feelings to your immediate family $(\mathrm{M}=3.76, \mathrm{SD}=1.119)$. And at a high level, the teacher is emotionally connected with their relatives $(\mathrm{M}=3.74, \mathrm{SD}=1.031)$. The teachers are able to talk to other people cautiously $(\mathrm{M}=3.60, \mathrm{SD}=1.104)$; this item got the lowest rating.

The level of social deprivation with regard to Interpersonal Communication was generally high, as evidenced by the overall mean of 3.68 and supported with standard deviation of 1.048 . This means that the teachers guided all participants in moving in the direction of excellence based on homegrown and global standards. To keep 


\section{EPRA International Journal of Research and Development (IJRD) \\ Volume: 6 | Issue: 6 | June 2021 \\ - Peer Reviewed Journal}

abreast with the changing times, the schools subject their coordinators to have a social activity with all the stakeholders.

\begin{tabular}{|l|c|c|c|}
\hline During this time of home quarantine & Mean & SD & Remarks \\
\hline Being able to talk to other people cautiously. & 3.60 & 1.074 & Agree \\
\hline Being able to get in touch with your friends and neighbors. & 3.64 & 1.049 & Agree \\
\hline Telling easily your feelings to your immediate family. & 3.76 & 1.119 & Agree \\
\hline Preferring to have sincere conversation to co-teachers. & 3.68 & 0.976 & Agree \\
\hline Being emotionally connected with your relatives. & 3.74 & 1.031 & Agree \\
\hline $\begin{array}{l}\text { Overall Mean }=3.68 \\
\text { Standard Deviation }=\mathbf{1 . 0 4 8} \\
\text { Verbal Interpretation = High }\end{array}$ & & \\
\hline
\end{tabular}

Legend:

\begin{tabular}{llll} 
Scale & Range & \multicolumn{1}{c}{ Remarks } & Verbal Interpretation \\
5 & $4.20-5.00$ & Always Observed & Very High \\
4 & $3.40-4.19$ & Often Observed & High \\
3 & $2.60-3.39$ & Sometimes Observed & Moderately High \\
2 & $1.80-2.59$ & Seldom Observed & Low \\
1 & $1.00-1.79$ & Never Observed & Very Low
\end{tabular}

Mean Level of mental health of Cluster 7 teachers in Calamba City, Laguna in terms of State of mind.

The teachers showed a high level of mental health with regard to state of mind. They did this by analyzing the pros and cons of every actions you have made $(\mathrm{M}=3.99, \mathrm{SD}=1.159)$ and by rationally understanding others people reasoning $(\mathrm{M}=3.87, \mathrm{SD}=1.166)$. Although verbally interpreted as high, the item with the lowest rating pertains to calmly assess the sudden change of events $(\mathrm{M}=3.76, \mathrm{SD}=0.874)$.

The level of mental health with regard to state of mind was generally high, as evidenced by the overall mean of 3.85 and supported with standard deviation of 1.015. This meant that state of mind is a mental health where decisions are set, resources wisely utilized, and the action was properly guided toward the consciousness of structural goals. The teachers must clearly comprehend others cognitive and be quick to response to changing environments.

Table 3. Level of mental health of Cluster 7 teachers in Calamba City, Laguna in terms of State of mind

\begin{tabular}{|l|c|c|c|}
\hline During this time of home quarantine & Mean & SD & Remarks \\
\hline Able to calmly assess the sudden change of events. & 3.76 & 0.874 & Agree \\
\hline $\begin{array}{l}\text { Able to reflect on the action and decision that you had } \\
\text { made. }\end{array}$ & 3.86 & 0.921 & Agree \\
\hline Capable of giving good and just reason. & 3.78 & 0.940 & Agree \\
\hline Rationally understand others people reasoning. & 3.87 & 1.166 & Agree \\
\hline $\begin{array}{l}\text { Analyze the pros and cons of every actions you have } \\
\text { made. }\end{array}$ & 3.99 & 1.159 & Agree \\
\hline $\begin{array}{l}\text { Overall Mean = 3.85 } \\
\text { Standard Deviation }=\mathbf{1 . 0 1 5} \\
\text { Verbal Interpretation = High }\end{array}$ & & & \\
\hline
\end{tabular}

Legend:

$\begin{array}{ll}\text { Scale } & \text { Range } \\ 5 & 4.20-5.00 \\ 4 & 3.40-4.19 \\ 3 & 2.60-3.39 \\ 2 & 1.80-2.59 \\ 1 & 1.00-1.79\end{array}$

Remarks Always Observed Often Observed Sometimes Observed Seldom Observed Never Observed

\author{
Verbal Interpretation \\ Very High \\ High \\ Moderately High \\ Low \\ Very Low
}




\section{EPRA International Journal of Research and Development (IJRD) \\ Volume: 6 | Issue: 6 | June 2021 \\ - Peer Reviewed Journal}

\section{Mean Level of mental health of Cluster 7 teachers in Calamba City, Laguna in terms of Behavior.}

Table 4. Level of mental health of Cluster 7 teachers in Calamba City, Laguna in terms of Behavior

\begin{tabular}{|l|c|c|c|}
\hline During this time of home quarantine & Mean & SD & Remarks \\
\hline Maintaining good appetite. & 3.89 & 1.052 & Agree \\
\hline Sleeping safe and sound during night hours. & 3.73 & 1.086 & Agree \\
\hline Still motivated to do assigned tasked. & 3.88 & 1.009 & Agree \\
\hline Having mood-swing. & 3.41 & 1.064 & Agree \\
\hline $\begin{array}{l}\text { Having perseverance and being driven even things } \\
\text { went wrong. }\end{array}$ & 3.77 & 0.932 & Agree \\
\hline $\begin{array}{l}\text { Overall Mean }=\mathbf{3 . 7 3} \\
\text { Standard Deviation }=\mathbf{1 . 0 4 0} \\
\text { Verbal Interpretation = High }\end{array}$ & & & \\
\hline
\end{tabular}

\section{Legend:}

\section{Scale Range Remarks}

4

3

2

1

$\begin{array}{ll}4.20-5.00 & \text { Always Observed } \\ 3.40-4.19 & \text { Often Observed } \\ 2.60-3.39 & \text { Sometimes Observed } \\ 1.80-2.59 & \text { Seldom Observed } \\ 1.00-1.79 & \text { Never Observed }\end{array}$

4.20-5.00

$3.40-4.19$

$180-2.59$

$1.00-1.79$

Verbal Interpretation
$\quad$ Very High
High
Moderately High
$\quad$ Low
Very Low

The teachers highly maintaining good appetite $(\mathrm{M}=3.89, \mathrm{SD}=1.052)$ and still motivated to do assigned tasked $(\mathrm{M}=3.88, \mathrm{SD}=1.009)$. Through sleeping safe and sound during night hours $(\mathrm{M}=3.73, \mathrm{SD}=1.086)$, the teachers became highly aware of the behavior being used. The item indicator with the lowest rating covered having moodswing ( $M=3.41, S D=1.064)$.

Generally, the behavior was highly observed at the teachers as indicated by the overall mean of 3.73 and supported with standard deviation of 1.040. This meant that the teacher was highly aware about their mental health and the benefits connected with the good behavior, and provided other behavioral openings for them.

Mean Level of mental health of Cluster 7 teachers in Calamba City, Laguna in terms of Thinking.

Table 5. Level of mental health of Cluster 7 teachers in Calamba City, Laguna in terms of Thinking

\begin{tabular}{|l|c|c|c|}
\hline During this time of home quarantine & Mean & SD & Remarks \\
\hline Still cautious of the things happening around. & 4.05 & 1.015 & Agree \\
\hline Can still focus on doing daily activities. & 3.88 & 0.998 & Agree \\
\hline Giving right decision needed in everyday life. & 3.91 & 0.962 & Agree \\
\hline Reflecting on the effects of situation. & 4.00 & 0.943 & Agree \\
\hline Maintaining presence of mind in doing the assigned tasked & 4.02 & 0.966 & Agree \\
\hline $\begin{array}{l}\text { Overall Mean }=\mathbf{3 . 9 7} \\
\text { Standard Deviation }=\mathbf{0 . 9 7 5} \\
\text { Verbal Interpretation = High }\end{array}$ & \multicolumn{3}{|l}{} \\
\hline
\end{tabular}

Legend:

\section{Scale $\quad$ Range Remarks \\ 5 \\ 4.20-5.00}

4

3

2

1
$3.40-4.19$

2.60-3.39

$1.80-2.59$

$1.00-1.79$
Always Observed Often Observed Sometimes Observed Seldom Observed Never Observed

\author{
Verbal Interpretation \\ Very High \\ High \\ Moderately High \\ Low \\ Very Low
}

The mental health of developing teachers' thinking was done at a high extent in the schools. The teacher is highly cautious of the things happening around $(\mathrm{M}=4.05, \mathrm{SD}=1.015)$ and maintaining presence of mind in doing the 


\section{EPRA International Journal of Research and Development (IJRD) \\ Volume: 6 | Issue: 6 | June 2021 \\ - Peer Reviewed Journal}

assigned tasked $(\mathrm{M}=4.02, \mathrm{SD}=0.966)$. However, the teachers can still focus on doing daily activities $(\mathrm{M}=3.88$, $\mathrm{SD}=0.988$ ). This item indicator got the lowest rating but still garnered a verbal interpretation of high.

The teachers were exposed to the thing happenings in the workplace. Generally, the teacher was highly empowered in maintaining presence of mind as evidenced by the overall mean of 3.97 and supported with standard deviation of 0.975 . The teachers knew that the group brought out the best in them, and when learning occurs without meddling with individual thinking.

Mean Level of mental health of Cluster 7 teachers in Calamba City, Laguna in terms of SelfEsteem

Table 6. Level of mental health of Cluster 7 teachers in Calamba City, Laguna in terms of Self-Esteem

\begin{tabular}{|l|c|c|c|}
\hline During this time of home quarantine & Mean & SD & Remarks \\
\hline Feeling accomplished in spite of any circumstances. & 3.85 & 0.965 & Agree \\
\hline Feeling worth of oneself. & 3.84 & 1.057 & Agree \\
\hline Feeling a sense of belongingness. & 3.89 & 1.027 & Agree \\
\hline Staying good and confident about oneself. & 3.93 & 1.020 & Agree \\
\hline Realizing the meaningful purpose of life. & 4.09 & 0.996 & Agree \\
\hline $\begin{array}{l}\text { Overall Mean }=\mathbf{3 . 9 2} \\
\text { Standard Deviation }=\mathbf{1 . 0 1 3} \\
\text { Verbal Interpretation }=\text { High }\end{array}$ & \multicolumn{3}{|l}{} \\
\hline
\end{tabular}

Legend:

\begin{tabular}{|c|c|c|c|}
\hline Scale & Range $I$ & & Verbal Interpretation \\
\hline 5 & $4.20-5.00$ & Always Observed & Very High \\
\hline 4 & $3.40-4.19$ & Often Observed & High \\
\hline 3 & $2.60-3.39$ & Sometimes Observed & Moderately High \\
\hline 2 & $1.80-2.59$ & Seldom Observed & Low \\
\hline 1 & $1.00-1.79$ & Never Observed & Very Low \\
\hline
\end{tabular}

The teacher was highly empowered by realizing the meaningful purpose of life $(\mathrm{M}=3.92, \mathrm{SD}=1.013)$ and by staying good and confident about oneself $(\mathrm{M}=3.93, \mathrm{SD}=1.020)$. However, the teachers feeling worth of oneself $(\mathrm{M}=3.84, \mathrm{SD}=1.057)$, as this item indicator got the lowest rating. The teachers were highly successful in promoting mental health in terms of self-esteem, as shown by the overall mean of 3.92 and supported with standard deviation of 1.013. The teachers were exposed in their field of work and know how to become productive that they can readily apply in the workroom. The teachers were highly successful in promoting mental health in terms of self-esteem, as shown by the overall mean of 3.92 and supported with standard deviation of 1.013 . The teachers were exposed in their field of work and know how to become productive that they can readily apply in the workroom.

Analysis on the relationship of social deprivation to the mental health among the Cluster 7 teachers on social interaction.

Table 7. Analysis on the relationship of social deprivation to the mental health among the Cluster 7 teachers on social interaction

\begin{tabular}{cccccc}
\hline Mental Health & beta & r-value & p-value & Interpretation & Analysis \\
\hline State of Mind & 0.581 & 0.768 & 0.0270 & high correlation & Significant \\
Behavior & 0.644 & 0.724 & 0.4518 & Not significant \\
Thinking & 0.672 & 0.723 & 0.0005 & high correlation & Significant \\
Self-Esteem & 0.720 & 0.736 & 0.0044 & high correlation & Significant \\
\hline
\end{tabular}

2021 EPRA IJRD | Journal DOI: https://doi.org/10.36713/epra2016 | www.eprajournals.com |207 | 


\section{EPRA International Journal of Research and Development (IJRD) \\ Volume: 6 | Issue: 6 | June 2021 \\ - Peer Reviewed Journal}

Legend

Scale Interpretation

$\pm 0.00 \quad$ no correlation, no relationship

$\pm 0.01- \pm 0.20$ very low correlation, almost negligible relationship

$\pm 0.21- \pm 0.40$ slight correlation, definite but small relationship

$\pm 0.41- \pm 0.70$ moderate correlation, substantial relationship

$\pm 0.71- \pm 0.90$ high correlation, marked relationship

$\pm 0.91- \pm 0.99$ very high correlation, very dependable relationship

$\pm 1.00 \quad$ perfect correlation, perfect relationship

Table 7 shows the analysis on the relationship of social deprivation to the mental health among the Cluster 7 teachers on social interaction.

The social deprivation that has a relationship to the teacher's social interaction include state of mind ( $\beta=581)$, thinking $(\beta=0.672)$, and self-esteem $(\beta=0.720)$. The beta coefficients indicate that for every standard unit increase in the teacher's social deprivation to the mental health there is a corresponding unit increase in social interaction.

The r-values for social interaction with state of mind $(r=0.768, p=0.0270)$, thinking $(F=0.723, p=0.0005)$, and self-esteem $(F=0.736, p=0.0044)$ are significant at probability level. This means that the mental health has a high correlation or marked relationship to the social interaction in terms of state of mind, thinking, and self-esteem of the teachers.

Analysis on the relationship of social deprivation to the mental health among the Cluster 7 teachers on interpersonal communication.

Table 8. Analysis on the relationship of social deprivation to the mental health among the Cluster 7 teachers on interpersonal communication

\begin{tabular}{cccccc}
\hline Mental Health & beta & r-value & p-value & Interpretation & Analysis \\
\hline State of Mind & 0.588 & 0.735 & 0.0063 & high correlation & Significant \\
Behavior & 0.697 & 0.740 & 0.2383 & Not significant \\
Thinking & 0.719 & 0.732 & 0.0000 & high correlation & Significant \\
Self-Esteem & 0.733 & 0.709 & 0.0011 & high correlation & Significant \\
\hline
\end{tabular}

Legend

Scale Interpretation

$\pm 0.00 \quad$ no correlation, no relationship

$\pm 0.01- \pm 0.20$ very low correlation, almost negligible relationship

$\pm 0.21- \pm 0.40$ slight correlation, definite but small relationship

$\pm 0.41- \pm 0.70$ moderate correlation, substantial relationship

$\pm 0.71- \pm 0.90$ high correlation, marked relationship

Table 8 shows the analysis on the relationship of social deprivation to the mental health among the Cluster 7 teachers on interpersonal communication.

The social deprivation that had a relationship to the teacher's interpersonal communication included state of mind $(\beta=588)$, thinking $(\beta=0.719)$, and self-esteem $(\beta=0.733)$. The beta coefficients indicated that for every standard unit increase in the teacher's social deprivation to the mental health there was a corresponding unit increase in interpersonal communication.

$\pm 0.91- \pm 0.99$ very high correlation, very dependable relationship

$\pm 1.00 \quad$ perfect correlation, perfect relationship 


\section{EPRA International Journal of Research and Development (IJRD) \\ Volume: 6 | Issue: 6 | June 2021 \\ - Peer Reviewed Journal}

The $r$-values for social interaction with state of mind ( $r=0.735, p=0.0063)$, thinking $(F=0.732, p=0.0000)$, and self-esteem $(\mathrm{F}=0.709, \mathrm{p}=0.0011)$ are significant at probability level. This meant that the mental health had a high correlation or marked relationship to the interpersonal communication in terms of state of mind, thinking, and self-esteem of the teachers.

Based on the data, it is shown that there is "a relationship between the social deprivation to the mental health among the Cluster 7 teachers in Calamba City" at 0.05 level of significance. It shows that the null hypothesis stating that "There is no significant relationship between the social deprivation to the mental health among the Cluster 7 teachers in Calamba City" is rejected, it can infer that there is "significant" relationship between them.

\section{CONCLUSION}

The r-values for social interaction are significant at probability level. This means that the mental health has a high correlation or marked relationship to the social interaction in terms of state of mind, thinking, and self-esteem of the teachers. Based on the data, it is shown that there is "a relationship between the social deprivation to the mental health among the Cluster 7 teachers in Calamba City" at 0.05 level of significance. It shows that the null hypothesis stating that "There is no significant relationship between the social deprivation to the mental health among the Cluster 7 teachers in Calamba City" is rejected, it can infer that there is "significant" relationship between them.

\section{ACKNOWLEDGEMENTS}

The researcher would like to extend his deepest gratitude with immeasurable joy to those who guided and supported him during the accomplishment of this research study.

First and foremost, to the greatest Almighty God, for giving him knowledge, strength, self-confidence and for the spiritual guidance that made this study possible.

Dr. Mario R Briones, President of Laguna State Polytechnic University, for his excellent leadership that made the university globally competitive.

A/P. Josephine H. Consebido, LPT, RPm, his thesis adviser, for the valuable insights, providing brilliant ideas and for the enormous guidance that made the researcher realize that he must make this study better.

Dr. Albina S. Bunyi, his subject specialist, for her broad knowledge and patience in giving constructive criticism to improve the study and providing in-dept insight in the construction of the self-made questionnaires.

Dr. Julie Rose P. Mendoza, his technical editor, for encouragement and ultimate enthusiasm in checking the study and providing support during the title defense till the completion of the research study.

Dr. Harold Origenes, his internal statistician, for all the support and guidance on his statistical treatment to come up a well understood research study.

Dr. Bengamin O. Arjona, his external statistician, for all the statistical treatments applied in the analysis of the gathered data.

A/P. Violeta Rana, his language critic, for the grammatical corrections that made the research better.

Ms. Abegail Viar, RGc, his external subject specialist, for her support and insightful recommendation and comments during the final defense of the research study.

Mr. Ralph Randel R. Rivera, RPm, and Mr. Wilfredo Fautisno, RPm, his questionnaire validator, for their comprehensive knowledge in helping a better construction of the self-made questionnaire and in making sure that the questionnaires are in lined on the purpose of the study.

Mrs. Edilberta A. De Guzman, his mother for giving him so much love and moral support.

His siblings, Mark Alfred A. De Guzman, Emelda DG. Olvida and Cecilia DG. Hernandez for supporting him financially and giving him strength and inspirations to finish the research study.

Mrs. Sandra B. Estimada his school head, for extending her hands in initiating in communicating the seven school heads of the target schools for the dissemination of the approval letters and dissemination of online questionnaires.

The School Division Superintendent, Susan Dl. Oribiana, and the Seven School Heads for their approval and indorsement in administering the online survey questionnaires to all randomly pic ninety-one teachers in Cluster 7, also for those official Ninety-one teachers as the respondents of the online survey questionnaires for their valuable cooperation of this study. 


\section{EPRA International Journal of Research and Development (IJRD) \\ Volume: 6 | Issue: 6 | June 2021 \\ - Peer Reviewed Journal}

Finally, all those people who prayed, inspired, and give piece of advice, and supported the researcher in coming up with the study.

\section{REFERENCES}

1. Adam Felman,(2020). Medically reviewed by Timothy J. Legg, Ph.D., CRNP. What is mental health? https://www.medicalnewstoday.com/articles/154543\#risk-factors

2. Faherty, Anna(2016) States of Mind: Experiences at the Edge of Consciousness. Kindle Edition, 256 pages Published February 4th 2016 by Profile Books. https://www.goodreads.com/book/show/28182895-states-of-mind

3. Hess E. (2016) Psychological States. In: Acting and Being. Palgrave Macmillan, London. https://doi.org/10.1057/978-1-349-95106-2_4

4. Kendra, Cherry,(2021). Medically reviewed byCarly Snyder, MD.The Psychology of Flow. https://www.verywellmind.com/what-is-flow-2794768

5. N., Pam M.S., "SELF-ESTEEM," in PsychologyDictionary.org, April 13, 2013, https://psychologydictionary.org/selfesteem/ (accessed May 17, 2021).

6. Naumovski, Vladimir \& Dana, Léo-Paul \& Pesakovic, Gordana \& Fidanoski, Filip. (2017). Why interpersonal communication is important in public administration?. Wspólczesne Problemy Ekonomiczne. 14. 55-77. 10.18276/wpe.2017.14-04.

7. Ormrod, J. E. (2017). Educational Psychology Developing Learners. Boston: Pearson. https://joerperez.wordpress.com/2014/11/29/behaviorism-and-social-cognitivetheory/\#: :text=Behaviorism\%20focuses\%20on\%20how\%20a, they\%20do\%20in\%20the\%20process.

8. Rigby,Amy(2017). How to improve your interpersonal communication skills. https://www.fingerprintforsuccess.com/blog/4-types-of-interpersonal-communication

9. Sarita, Robinson(2019). Isolation Has Profound Effects On The Human Body And Brain. https://www.sciencealert.com/isolation-has-profound-effects-on-the-human-body-and-brain-here-s-what-happens

10. Shraddha Bajracharya, "Interpersonal Communication," in Businesstopia, April 18, 2018, https://www.businesstopia.net/communication/interpersonal-communication-examples.

11. U.S. Department of Health \& Human Services, 200 Independence Avenue, S.W. Washington, D.C. 20201. https://www.mentalhealth.gov/basics/what-is-mental-health

12. Understanding Social Interaction. (2021, February 20). Retrieved May 18, 2021, from https://socialsci.libretexts.org/@go/page/8023

13. Zawadzki, M. J., Smyth, J. M., Costigan, H. J. (2015). Real-time associations between engaging in leisure and daily health and well-being. Annals of Behavioral Medicine, 49, 605-615.

14. 4.1D: Deprivation and Development - Social Sci LibreTexts

15. 61,653 Search Results - Keywords(social deprivation) - ScienceDirect

16. Behavior Change - an overview | ScienceDirect Topics

17. Behavioral Health: How Habits Affect Your Mental And Physical Health|Betterhelp

18. Behaviorism | Simply Psychology

19. Childhood violence exposure and social deprivation predict adolescent amygdala-orbitofrontal cortex white matter connectivity | Elsevier Enhanced Reader

20. Difference Between Social Cognitive Theory and Behaviorism | Difference BetweenHappy Brain, Happy Life | Psychology TodayHealth Behavior | Encyclopedia.com

21. How thinking affects your mind and life - The Hindu

22. How Thoughts Affect Mind and Body | Cognitive Healing

23. http://www.inrein.com/ijshr/IJSHR_Vol.5_Issue.2_April2020/IJSHR003.pdf

24. https://blog.smarp.com/interpersonal-communication-definition-importance-and-must-have skills\#: : text=Interpersonal\%20communication \%20is\%20the\%20process, expressions $\% 2$ C $\% 20$ body\%20language $\% 20$ and\%20gestures.

25. https://courses.lumenlearning.com/boundless-sociology/chapter/types-of-social-interaction/

26. https://dictionary.apa.org/thinking

27. https://journals.sagepub.com/doi/10.1177/0265407517691366

28. https://link.springer.com/chapter/10.1057/978-1-349-95106-2_4

29. https://onlinelibrary.wiley.com/doi/full/10.1111/jocn.15290

30. https://positivepsychology.com/self-esteem/

31. https://psychcentral.com/lib/how-to-raise-your-self-esteem/

32. https://psychcentral.com/lib/what-really-strengthens-self-esteem/

33. https://psychology.wikia.org/wiki/Introduction_to_thinking 


\section{SJIF Impact Factor 2021: 8.013| ISI I.F.Value:1.241| Journal DOI: 10.36713/epra2016 \\ ISSN: 2455-7838(Online) \\ EPRA International Journal of Research and Development (IJRD) \\ Volume: 6 | Issue: 6 | June 2021 \\ - Peer Reviewed Journal}

34. https://psychology.wikia.org/wiki/Social_deprivation\#: :text=Social\%20deprivation\%20is\%20a\%20form\%20of\%20de privation\%20in,to\%20social\%20groups\%20pursuing\%20hobbies\%20and\%20interests\%20etc

35. https://psychologydictionary.org/behavior/

36. https://psychologydictionary.org/selfesteem/\#: :text=Psychology\%20Definition\%20of\%20SELFESTEEM\%3A\%20the \%20degree\%20to\%20which,reflects\%20a\%20person\%27s\%20image\%20of\%20themself\%20and\%20their

37. https://psychologydictionary.org/thinking/\#: : text=Psychology\%20Definition\%20of\%20THINKING\%3A\%20noun.\%2 Omental\%20behavior\%20wherein,components\%20of\%20thought\%20are\%20experienced\%20or\%20manipulated.\%20I $n$

38. https://socialsci.libretexts.org/Bookshelves/Sociology/Book\%3A_Sociology_(Boundless)/05\%3A_Social_Interaction/5. 01\%3A_Understanding_Social_Interaction/5.1A\%3A_Understanding_Social_Interaction

39. https://study.com/academy/lesson/behavior-definition-lesson-quiz.html

40. https://study.com/academy/lesson/social-deprivation-definition-index.html

41. https://www.apa.org/monitor/2019/05/ce-corner-isolation

42. https://www.apa.org/pubs/journals/releases/amp-amp0000103.pdf

43. https://www.betterhelp.com/advice/behavior/what-is-behavior-modification-psychology-definition-techniquesapplications/

44. https://www.bing.com/search? $q=$ what + is + interpersonal + interaction $\& q s=S C \& p q=$ what + is + interperson + interaction $\& s c=131 \& c v i d=9 D 6 A 6 D F 6 D E 2 A 42 F 89 F C A D B 73939 F 413 D \& F O R M=Q B R E \& s p=1$

45. https://www.bing.com/search? $q=$ what + is + social + interaction $\& q s=E P \& p q=w h a t+i s+$ social + intera $\& s c=821 \& c v i d=F$ E6CC489B1EE43D09BCAE50D7D480634\&FORM=QBRE\&sp $=1$

46. https://www.britannica.com/topic/human-behavior

47. https://www.businesstopia.net/communication/interpersonal-communication-examples

48. https://www.fingerprintforsuccess.com/blog/4-types-of-interpersonal-communication

49. https://www.frontiersin.org/articles/10.3389/fpsyg.2014.00435/full

50. https://www.goodreads.com/book/show/28182895-states-of-mind

51. https://www.medicalnewstoday.com/articles/154543

52. https://www.medicalnewstoday.com/articles/154543\#risk-factors

53. https://www.mentalhealth.gov/basics/what-is-mental-health

54. https://www.mentalhealth.gov/basics/what-is-mental-health

55. https://www.merriam-webster.com/dictionary/analysis

56. https://www.ncbi.nlm.nih.gov/pmc/articles/PMC4471980/

57. https://www.nytimes.com/2017/06/12/well/live/having-friends-is-good-for-you.html

58. https://www.psychologydiscussion.net/thinking/thinking-types-development-and-tools-psychology/2058

59. https://www.psychologytoday.com/us/blog/fixing-families/201410/whats-your-state-mind

60. https://www.psychologytoday.com/us/blog/the-voices-within/201008/what-do-we-mean-thinking

61. https://www.researchgate.net/publication/261992861_Interpersonal_relationships_at_work

62. https://www.researchgate.net/publication/319476845_Why_interpersonal_communication_is_important_in_public_ad ministration

63. https://www.skillsyouneed.com/ips/interpersonal-communication.html

64. https://www.southuniversity.edu/news-and-blogs/2018/05/why-being-social-is-good-for-you

65. https://www.verywellmind.com/what-is-flow-2794768

66. https://www.verywellmind.com/what-isselfesteem 2795868\#: :text=In\%20psychology\%2C\%20the\%20term\%20self,beliefs \%2C\%20emotions\%2C\%20and\%2 Obehaviors.

67. Isolation Has Profound Effects on The Human Body And Brain. Here's What Happens (sciencealert.com)

68. Like It or Not, Emotions Will Drive the Decisions You Make Today | Psychology Today proponent of symbolic interaction theory - Bing

69. What Are the Factors That Affect Human Behavior? (reference.com)

70. What Is The Behavioral Learning Theory? (wgu.edu)

71. What Is the Social Learning Theory? (thoughtco.com) 